\title{
Negative impact of digital freedoms on Russian youth
}

\author{
Marina Cherkasova*, and Anna Taktarova \\ Rostov State Transport University, 344038, Rostov-on-Don, Russia
}

\begin{abstract}
Negative impact of Digital environment on the Youth is being increasingly mediated via novel communication technologies due to the uncontrolled channels of communication (digital freedoms). The analysis of this phenomena was conducted on the media texts (2016-2021) with a destructive component (murder, suicide, violence, revenge) with the aim of realization objective verbal behavioral model of generation $\mathrm{Z}$ as a new identity "online brain" in the format of transforming the axiosphere of adolescent discourse. We used objective pragmalinguistic analysis based on the specific perlocutionary intention of the sender of the text/information, accepted in pragma linguistic the last few years, as well aslexico-semantic method, contextual methods of analyzing words and constructions at the semantic level, the syntactic and descriptive analysis of the text according PMG (predicative-modal group). It was proved that axiological shifts in virtual reality caused the creation of new "online brain" formation with its own axiologem reflected in Real image of a digital adolescent.
\end{abstract}

\section{Introduction}

The influence of mass communication media on the formation of a young person's personality is currently being actualized as a result of a special way of creating, transforming, broadcasting and replicating information through various means of used communication and through digital devices. This process has both positive and negative features. We focus on the problem of the negative impact of digital freedoms, because teenagers have a large, and at the same time uncontrolled choice of ways and means of digital communication: social networks (Facebook, Instagram, Twitter, Tinder, Odnoklassniki, VKontakte) and their applications, instant messengers (Telegram, Viber, WhatsApp, Skype), blog platforms (LiveJournal), various video hosting services (TikTok, YouTube), and Internet games.

Now the Internet is not private, it is not a part of personal area [1], and the role of social media in the architecture of the communicative landscape continues to be relevant $[1,2,3]$. The impact of digital freedom on the formation of a young person's personality is increasing, as all these activities are involved in creating an image of our world and its values in accordance with traditions and culture based on human experience.

\footnotetext{
*Corresponding author: chercasovamn-rostov@rambler.ru
} 
Khvylya-Olinter N. A. points out that the Internet has become a threat to morality due to negative information [4] from social networks, blogs, and various Internet sites, which in most cases are not censored [5]. Mayatskaya O. [5], Emelin V. A. [6] emphasize the unpredictability of Internet activity and the opposition to upbringing and education as a result of virtual manipulation and digital destructive influence on young people with their unformed mental, psychological and social abilities. Most scientists, both Russian [5, 6] and foreign $[2,3,7,8,9]$ consider the uncontrolled Internet as a potential weapon of mass destruction, with the enormous power to transform a reasonable person with his or her value system in a very short period of time.

Various types of destructive [10,11] and deviant behavior [12, 13 Novikova] in the digital age have been the subject of researches: the Internet and drugs [13, 14], the Internet and alcohol [15], the Internet and sexual health [10, 16] cyberbullying [7, 17, 18, 19, 20], deadly stream, trolling, flood and chatting [21], gambling [2, 3, 22].

Haijiang Yan, Christina Brezing, Jeffrey L. Derevensky, et al. [2, 3] emphasize largescale mental disfunction as a result of human-Internet interaction when it comes to transferring the game space to the field of reality, resulting in shifts and disorder in emotional competence, attraction to prompts. The researchers note it as "poor emotional competence, cue-reactivity and craving, habitual addictive behaviors and enforced executive control".

Changes in the structure of emotional competence of young people when interacting with the Internet are also noted in the work [9], and the lack of elaboration of the problem is emphasized in the paper.

Significant negative changes in the social activity of the modern "digital person" are pointed and developed in the works of J. M. Hartley [8], P. Bourdieu [23]: the degree of withdrawal to the virtual space, dependence on virtual reality and the intention to be a certain type of person, for example, the style of luxury, which is a certain characteristic of a man, according to J. M. Hartley with a low cultural level and pronounced Internet addiction, when a person is used to do as the Internet demonstrates, "obey" and execute Internet commands. The formation of new specific forms of identity in the digital world is also discussed by the Russian researcher Emelin V. A. [6], who continues to develop the philosophy of "virtual realit" in this format through the theory of simulacra (from the Latin simulare - to be implemented) developed by Plato [24], Baudrillard, J. [25, 26], J. Deleuze [27].

This line of behavior, the use of so-called Internet practices (the transfer of Internet reality into real reality), drawn from the digital field, becomes the motto and lifestyle: "It's something posh people do" [8]. A similar position is taken by Bourdieu [23], who highlights such a feature of the modern digital generation as the creation of new axiological values: digital-persons themselves create a classification of value objects in accordance with their own real or virtual classification: "Social subjects, classified by their classifications, distinguish themselves by the distinctions they make, between the beautiful and ugly, the distinguished and the vulgar, in which their position in the objective classifications are expressed or betrayed" [23, p. 6]. Thus, we are talking about a shift in the emphasis in the axiosphere of the field of Digital communication, when the beautiful becomes vulgar, and the good becomes evil, and vice versa.

In this regard, we find interesting and reasonable the conclusion of Knekht N. P. [28] about the ability of the media space to reduce and accelerate social time because it is this potential of the Internet that is the reason for breaking the connection with both the future and the past. Time in the minds of teenagers is reduced to a moment of fame and popularity in any way and at any cost. The Internet being an extensive media platform and performing the function of communication becomes an opportunity for a teenager to demonstrate himself, real or created by himself by means of digital communication channels that allow 
to change your own "I" (ego). A special part is played by the mobile Internet, which allows to use photo-video-audio recording to take a picture of the present, go back to the past and often simulate the future (meaning the reactions of Internet users in the form of reposts, likes, comments, etc.).

The paper examines the negative impact of digital communications on the personality of Russian youth in terms of traditional media. To analyze and solve the problem, the authors hypothesize that modern media present the objective destructive behavioral model of generation $\mathrm{Z}$ as a new identity "online brain" in the format of transforming the axiosphere of adolescent discourse, and the negative impact of digital freedom on the personality of a young person is the potential possibility of transforming their "I" into a Virtual (Fake) image of an Internet user instead of a Real image.

\section{Methodology}

The subject of the study was the units of mass communication discourse. For the analysis traditional and e-media texts with a destructive component - murder, suicide, violence, revenge for 2014-2021 were extracted on random. 7 scenarios of destructive behavior were selected (Table. 2) in order to identify the transformation of the axiosphere of adolescent digital communications discourse and the role of the teenager as a digital person in this field. In this case the factor of direct or indirect involvement of a digital communicator (a particular digital platform (messenger, blog, social network, video, etc.)) in the behavioral deviant act and its role in the implementation of the aggressive behavioral attitude were taken into account.

The following tasks are set: to introduce the concept of "axiologem" of destructive conativity, to find and interpret them; to identify correlating pairs of axiologemes that have undergone transformation as a result of "digital freedom" and the reasons for such transformation that are reflected in the texts of mass communications; to analyze the axiologemes of positive, neutral and negative conation; to model the prospects of speech behavior of young people when journalists describe a destructive behavioral act in the context of global digitalization.

In the course of the study, the authors turned to an objective pragmalinguistic experiment [29: 256], which helps to study the speech communication of communicants through a system of text signs. To obtain reliable results we used the following methods:

- objective pragmalinguistic analysis based on the specific perlocutionary intention of the sender of the text/information (text/content is considered as a special communicative unit);

- lexico-semantic method;

- contextual methods of analyzing words and constructions at the semantic level;

- the syntactic analysis of the text dividing it into PMG-s (so-called predicative-modal group);

- a descriptive method (identification of differences among common patterns).

\section{Stages of the study}

This analysis was carried out according to the methodology developed in the works on pragmalinguistics by Taktarova A.V. [30]: 1. As an experimental material, the continuous sampling method was used to select texts with a given topic from the traditional and online publications in order to identify destructive scenarios and axiologemes that demonstrate an axiological shift in the axiosphere of virtual adolescent discourse. 2. The texts were divided into PMG-s, which are understood as a predicative-modal group. 3. Preparation of tabular 
matrices for filling them with labels indicating the presence of the desired axiological system in each PMG. 4. Searchin the texts speech axiologems with positive, neutral or negative connotations with further fixation them in a tabular matrix; 5. Calculating the frequency of actualization of positive, neutral, and negative axiologems; 6. Interpretation of the received data.

\section{Results of the study}

\section{The Transformation of the axiosphere as a result of transformation of reality}

As a result of various virtual media communications (games, movies, activities in messengers, etc.), Russian youth often cannot distinguish the concepts "life" and "death", they do not see an aggressive and destructive speech context, in which there has already been a shift in the semantics of the words or grammatical forms. The analysis of journalistic traditional and e-texts allowed us to identify an axiological shift in the assessment of such fundamental phenomena as "life", "deat", "aggression" in the real reality and virtual reality of a teenager.

Table 1.Axiologems "life", "death", "aggression": axiological shift based on differentiation of semantic components

\begin{tabular}{|l|l|l|}
\hline Axiologems & Real Reality & Virtual Reality \\
\hline Life & $\begin{array}{l}\text { start-end } \\
\text { limited period }\end{array}$ & $\begin{array}{l}\text { start-end-restart-start- } \\
\text { end-restart } \\
\text { unlimited period }\end{array}$ \\
\hline Death & the end point of life & $\begin{array}{l}\text { non-end point of life, } \\
\text { midpoint, reboot time, } \\
\text { start of new life }\end{array}$ \\
\hline $\begin{array}{l}\text { Aggression } \\
\text { (violence, murder, } \\
\text { insult) }\end{array}$ & $\begin{array}{l}\text { good, there will } \\
\text { encouragement (a } \\
\text { bonus in the form of } \\
\text { points in the game } \\
\text { (for killing someone), } \\
\text { getting additional } \\
\text { weapons, any } \\
\text { benefits, likes, } \\
\text { comments, attracting, } \\
\text { subscribers } \\
\text { constructive (vital) }\end{array}$ \\
\hline
\end{tabular}

On the basis of the identified axiological shifts found in the professional journalistic texts there is a conflict between reality and a person, the cognitive dissonance of the virtual and real behavioral scenario, expressed in the demonstration of "hedonistic violence", in which the sender of information using a digital channel becomes a screenwriter, director, actor (movie star, media person), newsmaker having its own audience and media critical zone (comments, reposts, likes, subscribers).

Reflection of the destructive scenario in professional texts of mass communication: the paradoxical nature of axiological pairs 
Table 2. Media reflection of an aggressive scenario

\begin{tabular}{|l|l|l|}
\hline \multirow{2}{*}{$\begin{array}{l}\text { Key points } \\
\text { Negative (Real Reality) }\end{array}$} & $\begin{array}{l}\text { Correlating axiological pairs that have undergone transformation } \\
\text { as a result of "digital freedom" }\end{array}$ \\
\cline { 2 - 3 } & \multicolumn{1}{|c|}{$\begin{array}{c}\text { Posivity (Virtual } \\
\text { Reality) }\end{array}$} \\
\hline $\begin{array}{l}\text { The willingness or even } \\
\text { more the desire to kill is } \\
\text { equal to willingness and } \\
\text { desire to die }\end{array}$ & kill & kill to die \\
\hline $\begin{array}{l}\text { School marginals } \\
\text { (outcasts) attack good } \\
\text { students and become } \\
\text { newsmakers, heroes: } \\
\text { the result is important } \\
\text { but not the way to } \\
\text { achieve such kind of } \\
\text { popularity. Outcasts are } \\
\text { short-term social } \\
\text { leaders. }\end{array}$ & outcasts, misfits, losers & hero, leader \\
\hline $\begin{array}{l}\text { Excellent student shot } \\
\text { the teacher }\end{array}$ & killer & hero \\
\hline $\begin{array}{l}\text { The attackers are trying } \\
\text { to commit suicide }\end{array}$ & attack, kill & commit suicide, die \\
\hline $\begin{array}{l}\text { Death is not the end, it } \\
\text { is the beginning of a } \\
\text { new life, reincarnation. }\end{array}$ & death is the end & not prohibited \\
\hline $\begin{array}{l}\text { Bloody assault, murder, } \\
\text { suicide, violence the } \\
\text { truth, the moment of } \\
\text { glory, the culmination } \\
\text { of life }\end{array}$ & forbidden, taboo & death is the game \\
\hline $\begin{array}{l}\text { Online demonstrations } \\
\text { of death, brutality, } \\
\text { battle, and bloody } \\
\text { assault are normal. }\end{array}$ & abnormal \\
\hline
\end{tabular}

\section{Prospects of speech behavior of Russian-speaking youth in covering a destructive behavioral act by the journalists}

As a result of the analysis of transformational shifts and correlating axiological pairs, an objective pragmalinguistic experiment was additionally conducted based on the material of 4 scenarios in order to identify the destructive component. For the first time, the category "axiologeme" is introduced as a speech signal of the hidden influence of the sender of information on the recipient. An axiologeme is a lexical unit with a code evaluation, which is accepted in the reference group of the message recipient and forms an approving, indifferent or disapproving attitude to the described events. By analogy the following influence plans were developed: "Positive-approving", "Neutral-indifferent" or "Negativedisapproving" (see Table 3). 
Table 3. The potential model of speech behavior of Russian-speaking youth in covering a destructive behavioral act by the journalists

\begin{tabular}{|c|c|c|c|c|c|c|c|}
\hline \multirow{2}{*}{ Plans } & \multicolumn{2}{|c|}{$\begin{array}{l}\text { Positive-approving } \\
\text { Influence Plan }\end{array}$} & \multicolumn{2}{|c|}{$\begin{array}{c}\text { Neutral- } \\
\text { indifferent } \\
\text { Influence Plan }\end{array}$} & \multicolumn{2}{|c|}{$\begin{array}{c}\text { Negative- } \\
\text { disapproving } \\
\text { Influence Plan }\end{array}$} & \multirow[t]{2}{*}{$\begin{array}{l}\text { Total } \\
\text { PMG }\end{array}$} \\
\hline & AbI \% & PMG & AbI\% & PMG & AbI\% & PMG & \\
\hline $\begin{array}{ll}\text { Scenario } & 1 . \\
\text { Suicidal } & \\
\text { Autumn } & \end{array}$ & 30 & 27 & 16.7 & 15 & 53.3 & 48 & 90 \\
\hline $\begin{array}{l}\text { Scenario } 2 . \\
\text { Dangerous } \\
\text { games with } \\
\text { death }\end{array}$ & 37.8 & 82 & 18.9 & 41 & 43.3 & 94 & 217 \\
\hline $\begin{array}{l}\text { Scenario } 3 . \\
\text { Suicide Virus }\end{array}$ & 36.2 & 110 & 18.1 & 55 & 45.7 & 139 & 304 \\
\hline $\begin{array}{lr}\text { Scenario } & 4 . \\
\text { Two } & 9^{\text {th }} \\
\text { grader girls } \\
\text { committed } \\
\text { suicide }\end{array}$ & 9.1 & 1 & 36.4 & 4 & 54.5 & 6 & 11 \\
\hline $\begin{array}{l}P M G \text { of the } \\
\text { plan }\end{array}$ & & 220 & & 115 & & 287 & 622 \\
\hline AvI & & $35.4 \%$ & & $18.5 \%$ & 46. & & \\
\hline
\end{tabular}

* Where AbI is the absolute data indicator as a percentage, and Avlis the average data indicator as a percentage for all three plans.

In the course of this analysis, PMGs were calculated for each scenario as the units of account of the pragmalinguistic experiment and their absolute indicator (AbI) as a percentage. For each of this four scenarios, the dominant plan was the "Negativedisapproving influence Plan" - 53.3\% (scenario 1), 43.3\% (scenario 2), 45.7\% (scenario 3), and $54.5 \%$ (scenario 4 ). The total figure for all three plans of $46.1 \%$ was derived using the following mathematical formula:

$$
\text { F plan }=\sum P M G \text { plan } \cdot 100 \% / \sum P M G \text { scenario }
$$

where $F$ is the frequency of the plan activity as a percentage, $\sum$ is PMGsum

In the headings and subheadings of the studied articles (2014-2020), the axiologems of destructive conativity were also found as a pragmatic feature of the sender of information to influence its potential recipient [30]: "There is no fear of death", "The Teachers are in Oblivion", "Children play with death", "The last step", "Hunger of Glory", "Virus suicides", "Crisis of Ideology", "When death is in friends", "Suicidal Autumn", "Dangerous games with Death", "Death Groups", "A schoolboy came out of the fog, took a knife out of his pocket", "What has Changed Them?" etc.

The average indicator (AvI) of the actualization of axiologems for all three negativedisapproving plans $(46.1 \%)$ indicates that the potential dominant of modern adolescent communication is destructive communication. Having digital opportunity and aiming to change their own "I" (Ego) Internet children try to demonstrate themselves as real or recreated by copying someone else's image with a component of destructiveness, thereby creating a negative virtual image for themselves. 


\section{Discussion}

The presentation of destructive behavior on the Internet and because of the Internet in Russian mass media demonstrates the transformation of the reality of adolescent communication, in particular, the transformation of axiological components [31]: minus has become a plus; evil has become good; death is preferred to life; they kill to die; human life itself is devalued; privacy becomes public domain one. We have so-called "hedonistic violence" and the creation of a subculture with new, contrary to universal values: fatal selfies, online death, etc.

Online activity is often transformed into a "game" and an interactive action [32]: a game with drugs, with death and life. The activity of various social groups on social web sites has a particular impact. The so-called "curators", using the choice of axiologies of cyberspace, skillfully manage their reference group, forcing them to broadcast their actions in the Internet space.

If we turn to the psychosocial stages of personality development of E. Erickson, then this age group is traditionally called "Youth" - as the fifth, and one of the most important stages of the human life cycle - the age when "No longer a child, but not yet an adult", finally forms its dominant identity of the Ego, which is key to establish its psychological and social well-being [33]. Often the negative influence of a hostile environment (an aggressive society, a media area with destructive content, bad family relationships, etc.) leads a teenagerto a confusion of roles and, as a result, violations of his or her identity.

\section{Conclusion}

The working hypothesis of our study was mostly confirmed. The materials of media demonstrate the axiological shifts in virtual reality: there is a transfer of that classification of values to the real reality: death is not perceived as something final, and death as a result of destructive behavior is not something complete: according to the young "digital man" there is a function of rebooting and reaching a new level - online demonstration brings popularity on the network, the video becomes virus, hence the increase in views, comments, likes, repostsand the image acts as a regulator of the speech behavior of young people. In the process of such communication, teenage users of the "online brain" formation do not create a Fake-image with a destructive component, which we were inclined to form in our hypothesis, but demonstrate a Real-image that fully reflects the destructive behavioral model of the modern generation.

\section{References}

1. O. Kachingwe, J. Salerno, B. Boekeloo, J. Fish, M. Geddings-Hayes, A. Faduma, E. Aparicio, Journal of Adolescence 82, 50-57 (2020). doi: 10.1016/j.adolescence.2020.06.005.

2. Yan Haijiang, C. Brezing, Qi Li, Kai Yu, Guozhen, Zhao, Progress in NeuroPsychopharmacology and Biological Psychiatry 109, (2021). doi: 10.1016/j.pnpbp.2021.110242.

3. C. Brezing, J. Derevensky, M. Potenza, Child and Adolescent Psychiatric Clinics of North America 19(3), 625-641 (2010). doi: 10.1016/j.chc.2010.03.012.

4. N.A. Khvylya-Olinter, Alma mater 5, 104-109 (2016). doi: 10.20339/AM.05-16.109. 
5. O. Mayatskaya, Bulletin of Science and Practice 12, 354-358 (2017). doi:10.20339/AM.05-16.104.

6. V.A. Emelin, National Psychological Journal 3, 86-97 (2016). doi: 10.11621/npj.2016.0313.

7. D. Aizenkot, Children and Youth Services Review 119, (2020). doi: 10.1016/j.childyouth.2020.105695.

8. J.M. Hartly, Media and Communication 6(2), 46-55 (2018). doi: 10.17645/mac.v6i2.1322.

9. A. Pelletier-Baldelli, L. Ives, Vijay, A. Mittal, Increased Internet use and poorer ability to manage emotions in youth at high-risk for psychosis, Schizophrenia Research: Cognition 2(4), 220-226 (2015). doi: 10.1016/j.scog.2015.08.002.

10. A.N. Alekhin, N.N. Koroleva, E.I. Ostasheva, Psychology in Russia: State of the Art. 8 (1), 125-138 (2015).

11. B. Piko, D. Prievara, D. Mellor, Children and Youth Services Review 77, 55-61 (2017). doi: 10.1016/j.childyouth.2017.04.007.

12. D.S. Novikova, Bulletin of the Ulyanovsk State Technical University 1, (2019). https://cyberleninka.ru/article/n/deviantnoe-povedenie, last accessed 2021/03/14.

13. M.E. Pozdnakova, Reforming Russia 8, 128-149 (2009).

14. G.U. Soldatova, S.V. CHikar'kova, A.A. Dreneva, S.N. Ilyuhina, We are responsible for the digital world: prevention of destructive behavior of teenagers and young people on the Internet (Kogito-Centr, Moscow, 2019)

15. M.A. Moreno, D'Angelo, J. Whitehill, Media and Communication 4(3), 50-59 (2016). doi: http://dx.doi.org/10.17645/mac.v4i3.529.

16. L. Cory, Armstrong, Hull KevinDigital Journalism 4(2), 247-265 (2016). doi: 10.1080 / 21670811.2015.1040043.

17. A.V. Putintseva, Bulletin of Ufa law institute (2020). https://cyberleninka.ru/article/n/razvitie-fenomena-kiberbulling-analiz-podhodov-kopredeleniyu, last accessed 2021/03/10.

18. E.G. Dozorceva, D.V. Kiryuhina, Prikladnaya yuridicheskaya psihologiya 1(50), 80-87 (2020). doi: 10.33463/2072-8336.2020.1(50).080-087.

19. L. Edwards, A. Kontostathis, C. Fisher, Media and Communication 4(3), 71-78 (2016). doi: $10.17645 / \mathrm{mac} . v 4 i 3.525$.

20. K.D. Hlomov, D.G. Davydov, A.A. Bochaver, Psychology and law 9(2) (2019). https://publications.hse.ru/en/articles/291443597, last accessed 2021/ 03/10. DOI: 10.17759/psylaw.2019090219.

21. A.M. Vasilyeva, A.I. Gorokhova, Mezhdunarodnyj nauchno-issledovatel'skij zhurnal 12 (102) (3), (2020). https://www.elibrary.ru/item.asp?id=44497289, last accessed 2021/ 03/10. DOI: 10.23670/IRJ.2020.102.12.095.

22. V.V. Artamonova, Historical and Social-Educational Idea 10(2/2) (2018). https://cyberleninka.ru/article/n/razvitie-kontseptsii-geymifikatsii-v-xxi-veke last accessed 2021/03/09. DOI: 10.17748/2075-9908-2018-10-2/2-37-43.

23. P. Bourdieu, Distinction - A social critique of the judgement of taste (MA: Harvard University Press, Cambridge, 1984).

24. Plato, Sophist, Sobranie sochineniy (Vol. 2., Moscow, 1993).

25. J. Baudrillard, Khudozhestvennyy zhurnal 3, 33-36 (1994)

26. J. Baudrillard, Simulacra and Simulation (Moscow, 2015). 
27. J. Deleuze, Logic of Sense (Bloomsbury Publishing PLC, London, 2015)

28. N.P. Knekht, Economic and Social and Humanitarian Researches 2(2), 115-122 (2014).

29. G.G. Matveeva, A.V. Taktarova, Vestnik Volzhskogo universiteta imeni V.N. Tatishcheva 4(17), 252-258 (2014).

30. A.V. Taktarova, Pragmalinguistic aspect of speech behavior of Russian-speaking and German-speaking journalists in synchrony and diachrony (2016). https://www.elibrary.ru/item.asp?id=30436519, last accessed 2021/ 03/10.

31. M.N. Cherkasova, Transformation of axiological sphere of media discourse: Modern media in focus of media criticism (Rostov-on-Don, 2019).

32. E.A. Makarova, E.L. Makarova, International Electronic Journal of Elementary Education 12 (2), 157-165 (2019). doi: 10.26822/iejee.2019257663.

33. V.L. Alikhanova, Journal The Times of science 3-12, (2018). 